\title{
PENGARUH STRATEGI PEMBELAJARAN INFORMATION SEARCH TERHADAP KEMAMPUAN MENULIS TEKS EKSPLANASI KOMPLEKS SISWA KELAS XI SMK PGRI 2 PALEMBANG
}

\author{
Renta Sri Mariana Siregar ${ }^{1}$, Hetilaniar $^{2}$, Zainal Abidin ${ }^{3}$ \\ rentasiregar20@gmail.com ${ }^{1}$ \\ Universitas PGRI Palembang ${ }^{1,2,3}$
}

\begin{abstract}
Abstrak--Pengaruh Strategi Pembelajaran Information Search Terhadap Kemampuan Menulis Teks Eksplanasi Kompleks Siswa Kelas XI SMK PGRI 2 Palembang. Rumusan Masalah dalam penelitian ini adalah apakah terdapat pengaruh strategi pembelajaran Information Search terhadap kemampuan menulis teks eksplanasi kompleks kelas XI SMK PGRI 2 Palembang. Tujuan penelitian ini adalah untuk mengetahui apakah terdapat pengaruh strategi Information Search terhadap kemampuan menulis teks eksplanasi kompleks kelas XI SMK PGRI 2 Palembang. Metode penelitian yang digunakan adalah metode eksperimenOne-Grup Postest Design. Populasi dalam penelitian ini adalah siswa kelas XI SMK PGRI 2 Palembangyang terdiri dari 3 kelas. Teknik pengumpulan data yang dilakukan dengan menggunakan tes dan wawancara. Teknik analisis data menggunakan uji normalitas, uji homogenitas dan uji hipotesis. Dari hasil perhitungan statistik uji-t dua pihak, diperoleh $t_{\text {hitung }}=3,56$ dan $t_{\text {tabel }}$ dengan taraf signifikan $0,05 \%$ dengan diperoleh $\mathrm{t}_{\text {tabel }}=1,68$. Demikian, ternyata $\mathrm{t}_{\text {hitung }}>\mathrm{t}_{\text {tabel }}(1-\alpha)(3,56>1,68)$. Maka, hipotesis tentang ada pengaruh yang signifikan dengan menggunakan strategi pembelajaran Information Search terhadap kemampuan menulis teks eksplanasi kompleks siswa kelas XI SMK PGRI 2 Palembang" Ha diterima. Hal tersebut menunjukkan adanya pengaruh strategi pembelajaran information search terhadap kemampuan menulis teks eksplanasi kompleks siswa kelas XI SMK PGRI 2 Palembang.
\end{abstract}

Kata kunci: Strategi Pembelajaran, menulis teks eksplanasi kompleks, Siswa

Artikel Diterima:19-08-2020 Artikel Disetujui:26-02-2021 Artikel Dipublikasi:28-02-2021

Corresponden Author: Renta Siregar E-mail: rentasiregar20@gmail.com

DOI: http://dx.doi.org/10.31851/pembahsi.v11i1.4715

\section{PENDAHULUAN}

Pembelajaran merupakan suatu kegiatan yang bermakna pada peserta didik karena sebagai penentu utama dalam keberhasilan pendidikan (Hidayat, 2017). Pembelajaran juga merupakan proses komunikasi dua arah, yang dilakukan oleh pihak guru sebagai pendidik, sedangkan belajar dilakukan oleh peserta didik. Dalam proses pembelajaran peserta didik diharapkan memperhatikan guru saat pembelajaran berlangsung, terutama dalam belajar teks eksplanasi kompleks.

Kemampuan Menulis merupakan salah satu aspek kemampuan bahasa yang harus dikuasi siswa. Kebiasaan menulis dapat mengembangkan kemampuan berpikir dan meningkatkan pengetahuan siswa. Menurut Tarigan (2005) bahwa menulis adalah menurunkan atau melukiskan lambang-lambang grafis yang menghasilkan suatu bahasa yang dipahami oleh seseorang sehingga orang lain.

Menulis merupakan kegiatan yang dilakukan oleh siswa. Keterampilan menulis menjadi keterampilan paling akhir setelah menyimak, berbicara dan membaca. Hal ini disebabkan karena seseorang akan mampu menulis jika menguasai keterampilan berbahasa sebelumnya. Menurut Tarigan (2008), berpendapat bahwa keterampilan menulis dapat dikuasai dan diperoleh dengan jalan praktik dan latihan yang tersistematis. Oleh karena itu, untuk mampu menulis demgan baik siswa harus mampu berlatih secara intensif agar dapat mengasah keterampilan menulisnya.

Menulis adalah suatu proses yang di lakukan melalui tahap yang harus dikerjakan dengan mengarahkan 
keterampilan dan seni sehingga semuanya berjalan dengan efektif. Menulis merupakan hasil kerja yang kreatif dengan memerlukan langkah-langkah yang sistematis, sama halnya dengan menulis teks eksplanasi kompleks. Menulis teks eksplanasi kompleks yang merupakan satu di antara bentuk tulisan ilmiah yang memiki fakta tentang suatu kejadian atau peristiwa alam dan sosial.

$$
\text { Menurut Dalman }
$$

mengemukakan Menulis ialah suatu kegiatan komunikasi berupa penyampaian pesan (informasi) dengan tertulis kepada pihak lain dengan menggunakan bahasa tulis sebagai alat atau mediannya. Aktifitas menulis melibatkan beberapa unsur-unsur, yaitu: penulis sebagai penyampaian pesan, isi tulisan, saluran atau media, dan pembaca dapat membaca lambang-lambang grafis tertentu dan dapat memahami bahasa dan grafis tersebut.

Teks Eksplanasi Kompleks merupakan teks yang berisi tentang proses atau peristiwa fenomena alam, sosial, ilmu pengetahuan, budaya dan lainnya dengan menjelaskan proses terjadinya sesuatu menurut prinsip sebabakibat. Sejalan dengan pendapat Engkos Kosasih (2017), Teks Eksplanasi merupakan teks yang menjelaskan suatu proses dan peristiwa tentang asal-usul, proses atau perkembangan suatu fenomena, mungkin berupa peristiwa alam, sosial, atau budaya.

Strategi pembelajaran memiliki keterkaitan yang kuat dengan tujuan pembelajaran (Suyati, 2019). Keterkaitan tersebut dapat dilihat dari gambaran perilaku maupun kompetensi yang harus dimiliki oleh siswa selama dan setelah pelajaran dengan cara yang harus ditempuh untuk mencapai tujuan tertentu. Sedangkan strategi merupakan salah satu kompenen yang ada dalam kegiatan pembelajaran karena untuk mencapai tujuan pembelajaran maupun dalam upaya kemampuan siswa diperlukan adanya suatu metode yang efektif. Menggunakan strategi harus dapat menciptakan terjadinya interaksi antara siswa dengan siswa maupun antara siswa dengan guru sehingga proses pembelajaran dapat dilakukan dengan maksimal. Strategi atau metode mengajar memiliki fungsi yang efektif dalam pembelajaran yaitu sebagai alat dan cara untuk mencapai tujuan pembelajaran.

StrategiInformation Search adalah strategi mencari informasi yang mana tujuan dari strategi ini adalah dapat memacunya daya pikir dalam mencari informasi lengkap. Strategi ini bisa disamakan dengan ujian buka buku (open book). Secara berkelompok siswa mencari informasi yang menjawab pertanyaan-pertanyaan yang diberikan kepada mereka.

Strategi Information Search merupakan strategi pembelajaran mencari informasi dapat diperoleh melalui koran, buku paket, majalah atau internet. Hal tersebut digunakan agar siswa dapat memiliki informasi lebih tentang informasi tersebut. Dan agar siswa aktif mencari informasi, maka guru aktif mencari informasi penting. Pencarian informasi yang dilakukan secara kelompok yang bertujuan agar permasalahan tersebut terselesaikan dengan cepat dan apabila siswa malu bertanya kepada guru sehingga siswa dapat bertanya dengan teman sekelompoknya, sehingga terjadi tukar pendapat ide antar kelompok. Strategi Information Search yaitu suatu cara yang digunakan oleh guru dengan maksud siswa untuk menjawab pertanyaanpertanyaan yang diajukan baik guru maupun siswa itu sendiri.

Menurut

Hamruni (2011),Information Search adalah suatu strategi yang memberikan kesempatan kepada siswa untuk belajar di luar kelas, keluar dari kungkungan tembok dan dinding kelas, yang terkadang terasa bosan dan jenuh. Mereka bisa belajar 
diperpustakaan, warnet, mencari jurnal, dan sumber-sumber belajar yang lain. Strategi ini dapat memacu peserta didik untuk mencari dan menemukan informasi yang berkaitan dengan materi pembelajaran, sehingga dapat memecahkan masalah atau pertanyaan. Penggunaan strategi Information Search belum pernah diterapkan dalam proses kegiatan belajar mengajar dengan demikian penulis tertarik untuk menggunakan informasi lengkap yang di harapkan dapat meningkatkan hasil belajar yang kognitif (pengetahuan) dan meningkatkan hasil belajar yang efektif (sikap).

Berdasarkan uraian diatas dapat disimpulkan bahwa Strategi Pembelajaran Information Search adalah suatu strategi pembelajaran aktif peserta didik untuk mencari dan menemukan informasi yang berkaitan dengan materi pembelajaran, sehingga dapat memecahkan suatu masalah atau pertanyaan. Berdasarkan hasil observasi peneliti dengan kurangnya kemampuan menulis siswa, khususnya menulis teks eksplanasi disebabkan oleh beberapa faktor masalah diantaranya, (1) minatnya siswa belajar teks eksplanasi yang masih rendah. (2) kurangnya kebiasaan menulis menyebabkan siswa menjadi terbebani apabila mendapatkan tugas untuk menulis sebuah teks. (3) siswa membutuhkan waktu yang cukup lama dapat menuangkan ide dengan baik. (4) siswa kurang bisa mengembangkan bahasa.

Alasan memilih sekolah SMK PGRI 2 Palembang karena peneliti berharap penerapan perkembangan Strategi Pembelajaran Information Search ini memberikan dan memacu siswa kelas mencari informasi lengkap dengan menulis teks eksplanasi kompleks.

Pembatasan lingkup masalah dalam penelitian ini, yaitu sebagai berikut.

1) Pengaruh yang dimaksud adalah Strategi Pembelajaran Information
Search terhadap kemampuan menulis teks ekplanasi Kompleks dengan meningkatkan hasil belajar siswa.

2) Hasil belajar yang dimaksud adalah hasil belajar setelah diterapkan strategi pembelajaran Information Search dengan maksimal untuk menyatakan kegembiraan dalam materi teks eksplanasi kompleks.

Untuk permasalahan dalam penelitian ini adalah apakah terdapat pengaruh strategi pembelajaran Information Search terhadap kemampuan menulis teks eksplanasi kompleks kelas XI SMK PGRI 2 Palembang?

Tujuan penelitian yang ingin dicapai dalam penelitian ini adalah untuk mengetahui apakah terdapat pengaruh strategi Information Search terhadap kemampuan menulis teks eksplanasi kompleks kelas XI SMK PGRI 2 Palembang.

Menurut Dalman (2015), mengemukakan Menulis ialah suatu kegiatan komunikasi berupa penyampaian pesan (informasi) secara tertulis kepada pihak lain dengan menggunakan bahasa tulis sebagai alat atau medianya. Aktifitas menulis mengikuti beberapa unsur, yaitu: penulis sebagai penyampampaian pesan, isi, tulisan, saluran media, dan dan pembaca. Menurut Nurgiyantoro (2009), bahwa Menulis ialah aktifitas mengungkapkan gagasan melalui media bahasa. Batasan yang dibuat sangat sederhana, menurutnya menulis hanya sekedar mengungkapkan ide, gagasan, atau pendapat dalam bahasa tulis, lepas dari mudah tidaknya tulisan tersebut menyatakan menulis sebagai tindakan pemindahan pikiran atau perasaan dalam bahasa tulis dengan menggunakan lambang-lambang atau grafem.

Menurut Tarigan (2008) Menulis merupakan suatu keterampilan berbahasa yang dipergunakan untuk berkomunikasi secara tidak langsung, tidak secara tatap muka dengan orang lain. Dengan 
mencermati pendapat tersebut, dapat disimpulkan bahwa menulis tidak hanya mengungkapkan gagasan melalui media bahasa tulis saja tetapi juga menyeluruhi tulisan tersebut agar dapat di pahami oleh pembaca.

Setiap penulis harus mempunyai tujuan yang jelas dan tulisan yang akan ditulisnya. Tujuan dari menulis adalah supaya tulisan yang dibuat dapat dibaca dan dipahami dengan benar oleh orang lain yang mempunyai kesamaan pengertian terhadap bahasa yang digunakan. Sedangkan menurut Suparno dan Mohamad Yunus (2008), tujuan yang akan dicapai seseorang penulis bermacam-macam sebagai berikut.

a. Menjadikan pembaca ikut berpikir dan bernalar.

b. Membuat pembaca tahu tentang hal yang diberitakan.

c. Menjadikan pembaca beropini.

d. Menjadikan pembaca mengerti dan paham.

e. Membuat pembaca terpersuasi oleh isi karangan.

f. Membuat pembaca senang dengan menghayati nilai-nilai yang dikemukakan seperti nilai kebenaran, nilai pendidikan, nilai sosial, nilai moral, dan nilai estetika.

Manfaat menulis bagi seseorang, menulis dalam hal ini adalah menyampaikan sesuatu dalam bentuk bahasa tulis. Dengan tulisan tangan maupun media mesin pengetik, isi tulisan boleh berupa pendapat, gagasan dan pemikiran seseorang. Hasil tulisan seseorang minimal untuk dibaca sendiri, menulis dengan tujuan bukan untuk orang lain. Mungkin dalam konteks ini adalah sebuah dari catatan perjalanan hidup.

Banyak manfaat jika menulis ditujukan untuk seorang penulis, sebagai berikut.

1) Menulis berarti menciptakan komunikasi dengan diri sendiri maupun orang lain.
2) Kebiasaan menulis akan mengasah dan mempertajam kemampuan diri sendiri dengan berbahasa tulis.

3) Dengan menulis akan membantu orang lain dalam mengahadapi dan memecahkan masalah yang sama dengan yang dihadapi si penulis.

4) Menulis dapat mengasah daya nalar dan daya ingat seorang penulis.

5) Melatih ketajaman untuk berkonsentrasi.

6) Menulis kreatif akan menjadi sumber penghasilan.

7) Aktivitas menulis dapat memperbanyak teman dan sahabat.

8) Menulis adalah sarana aktualisasi dari seseorang.

9) Kemampuan menulis menjadi sebuah proses dari prestasi.

10) Kegiatan menulis mendatangkan kepuasan hati.

11) Menulis menambah pengetahuan dan wawasan seseorang.

Menurut Hamruni (2011), Strategi pembelajaran adalah penataan cara-cara atau langkah-langkah dibawah kondisi pembelajaran yang berbeda guna mencapai tujuan atau kompetensi hasil pembelajaran. Strategi Information Search merupakan metode yang bisa disamakan dengan open-book. Tim-tim di kelas mencari informasi untuk menjawab pertanyaan yang diajukan oleh guru. Strategi ini sangat membantu menjadikan materi yang biasa-biasa saja menjadi lebih baik dan menarik.

Menurut Zainal Arifin (2012), Strategi Information Search adalah strategi aktif yang memberikan kesempatan peserta didik untuk mencari informasi melalui media atau sarana apa pun yang memungkinkan mereka mendapat informasi tersebut. Dengan cara ini, guru dapat membagi peserta didik kedalam kelompok agar informasi yang diperoleh peserta didik dapat aktif, guru mengarahkan setiap kelompok 
belajar ditempat atau dengan media berbeda.

Menurut Hamruni (2011), Strategi Information Search adalah suatu strategi yang memberikan kesempatan kepada siswa untuk belajar di luar kelas, keluar dari kungkungan tembok dan dinding kelas, yang terkadang terasa sumpek dan penuh aturan. Mereka bisa belajar diperpustakaan, warnet, mencari jurnal, dan sumber-sumber belajar yang lain. Strategi ini dapat memacu peserta didik untuk mencari dan menemukan informasi yang berkaitan dengan materi pembelajaran, sehingga dapat memecahkan masalah atau pertanyaan.

Berdasarkan penjelasan dari teoriteori tersebut, dapat disimpulkan bahwa strategi pembelajaran Information Search dapat membuat materi belajar yang biasabiasa saja menjadi lebih tertarik dalam pembelajaran karena melibatkan peserta didik dalam mencari sebanyakbanyaknya informasi tentang materi pembelajaran.

Menurut Melvin L. Silberman (2007)langkah-langkah dalam strategi pembelajaran

Information

Search(Pencarian info) adalahsebagai berikut.

a. Guru menyiapkan sumber yang bisa mencakup :

1) Buku Panduan

2) Dokumen

3) Buku Teks

4) Panduan referensi

5) Informasi yang diakses melalui komputer

b. Membagikan pertanyaan-pertanyaan tentang topiknya.

c. Memberikan arahan siswa untuk mencari informasi dalam tim-tim kecil.

bersahabat bisa mewujudkan partisipasi.

d. Bahaslah jawaban di depan kelas. Perluas jawaban untuk memperluas cakupan pembelajaran.
Teks Eksplanasi merupakan teks yang berisi tentang proses mengapa dan bagaimana kejadian-kejadian alam, sosial, ilmu pengetahuan, budaya, dan lainnya dapat terjadi. Suatu kejadian baik kejadian alam maupun kejadian sosial yang terjadi di sekitar kita, selalu memiliki hubungan sebab akibat dan memiliki proses.

Menurut Mulyadi dkk (2016), Teks Eksplanasi adalah teks yang menceritakan prosedur atau proses terjadinya sesuatu. Dengan adanya teks tersebut, kita dapat memperoleh gambaran tentang latar belakang terjadinya secara jelas. Teks eksplanasi menggunakan fakta dan pernyataan yang memiliki hubungan kausalitas (sebabakibat). Menurut Mahsun (2014), Teks Eksplanasi memiliki fungsi sosial menjelaskan atau menganalisis proses muncul atau terjadinya sesuatu.

Berdasarkan uraian di atas tentang teks eksplanasi kompleks dapat disimpulkan, teks eksplanasi merupakan teks yang menjelaskan suatu proses atau peristiwa tentang asal-usul, proses atau perkembangan suatu fenomena. Dengan adanya teks eksplanasi tersebut, kita dapat memperoleh gambaran tentang latar belakang terjadinya secara jelas. Teks eksplanasi ini sangat menarik siswa dan mengembangkan sikap siswa, keterampilannya dan pengetahuan siswa serta menjelaskan atau menganalisis proses muncul atau terjadinya sesuatu.

Sama seperti teks pada umumnya, teks eksplanasi memiliki ciri-ciri khusus yang dapat membantu kita mengidentifikasi apakah sebuah teks termasuk dalam teks eksplanasi ataupun tidak. Sebelumnya, Sangat mudah membedakan teks eksplanasi dengan teks lainnya. Dikarenakan teks eksplanasi mempunyai ciri-ciri yang harus dipenuhi, sebagai berikut:

1) Memuat informasi-informasi fakta. 
2) Membahas suatu fenomena yang bersifat keilmuan atau ilmu pengetahuan.

3) Bersifat Informasi dan tidak berusaha menpengaruhi pembaca untuk mempercayai hal yang dibahas di dalam teks.

4) Memiliki/menggunakan sequence markers, seperti pertama, kedua, ketiga, dsb atau pertama, berikutnya, terakhir.

5) Struktur teksnya terdiri dari 3 jenis yaitu: penjelas atau sebab akibat, serta interprestasi.

\section{Tanah Longsor}

Longsor dimaksud sebagai pergerakan tanah yang ambrol atau lengser dari dataran tinggi ke dataran yang ada di bawahnya. Tanah longsor ini termasuk juga jadi satu diantara bencana alam yang beresiko apabila daerah yang tertimpa longsoran adalah lokasi padat masyarakat. Tanah longsor yang berlangsung di lokasi padat masyarakat, lahan pertanian serta perikanan, jalur transportasi pasti juga akan menyebabkan banyak kerugian serta kemungkinan yang tidak dapat diremehkan karena banyak masalah tanah longsor yang berlangsung mengakibatkan beberapa orang-orang wafat karena tertimbun material tanah.

Tanah longsor yaitu satu momen geologi yang berlangsung karna masa material seperti bebatuan dengan bermacam ukuran, tanah, atau gumpalan tanah alami gerakan yang dikarenakan oleh tiga type aspek, yaitu style gravitasi, aspek pendorong serta aspek penyebab.Aspek pendorong adalah cirikhas bermaterial tanah tersebut sesaat aspek penyebab yaitu yang mengakibatkan material tanah itu bergerak serta lengser dari tempat awalannya. Aspek penyebab tanah longsor ada berbagai macam macamnya, yaitu aspek alam serta aspek manusia.
Untuk dapat mengetahui menulis teks eksplanasi kompleks dengan baik dan benar, peserta didik harus memahami bagaimana langkah-langkah dalam menulis teks eksplanasi dengan Strategi Information Search pada umumnya. Menurut Sobandi (2014). Langkahlangkah menulis teks eksplanasi dengan Information Search yaitu, sebagai berikut:

1. Tersedia referensi terkait topik pembelajaran tertentu sesuai kompetensi Dasar/Indikator/Tujuan pembelajaran.

2. Menentukan kompetensi dari topik informasi tertentu.

3. Mengumpulkan bahan pembelajaran.

4.Menjelaskan materi pelajaran terkait dengan topik tersebut.

5. Melakukan kesimpulan, klarifikasi dan tindak lanjut.

Setelah peneliti membaca dan mempelajari beberapa teori karya ilmiah sebelumnya, penulis menemukan teori yang ada kaitan dengan judul yang akan penulis peneliti, yaitu:

1) Skripsi Nismalena Jurusan Bahasa dan Seni Universitas PGRI Palembang Tahun 2016 berjudul "Pengaruh Model Pembelajaran Problem Based Instruction (PBI) Terhadap Kemampuan Menulis Teks Wawancara Menjadi Narasi Pada Siswa Kelas VII SMP Negeri 31 Palembang". disimpulkan bahwa model pembelajaran Problem Based Instruction (PBI) adalah suatu model pembelajaran yang didasarkan pada banyaknya permasalahan yang membutuhkan penyelidikan autentik yakni penyelidikan yang membuhkan penyelesaian nyata dari permasalahan yang nyata. Persamaan terhadap pembahasan peneliti adalah kutipan pengertian kemampuan menulis. Sedangkan perbedaannya adalah terletak pada strategi pembelajaran yang digunakan. 
2) Jurnal penelitian yang dilakukan oleh Suci Ramodhona, Nurhayati dan Nurbaya mahasiswa Megister Pendidikan Bahasa Indonesia Universitas Sriwijaya melakukan penelitian yang berjudul "Pengaruh Model Information Search Terhadap Kemampuan Menulis Karangan Ekspositif'.Kesimpulan dari penelitian ini adalah bahwa model Information Search terbukti lebih berpengaruh untuk meningkatkan kemampuan menulis karangan ekspositif siswa kelas X SMA Sriajata Negara Palembang. Persamaan pembahasan terhadap peneliti adalah mengutip pengertian Information Search dan Pengertian Menulis. Sedangkan perbedaannya pada penelitian sebelumnya membahas kemampuan menulis karangan ekspositif, sedangkan penelitian ini tentang kemampuan menulis teks eksplanasi kompleks.

Kerangka pemikiran menurut Sugiyono, bahwa seorang peneliti harus menguasai teori-teori ilmiah sebagai dasar menyusun kerangka pemikiran yang menghasilkan hipotesis. Kerangka pemikiran merupakan penjelasan sementara terhadap gejala yang menjadi objek permasalahan.

Ketika proses pembelajaran yang berlangsung menggunakan strategi yang tidak sesuai dengan kecerdasan peserta didik maka proses penerimaan materi pembelajaran tidak akan berjalan seperti yang diharapkan. Kemungkinan peserta didik akan cepat merasa bosan. Karena proses pembelajaran yang membosankan bagi peserta didik membuat minat dan motivasi belajar peserta didik menjadi rendah.Adapun rancangan konseptualnya yaitu tentang proses kegitan belajar siswa dengan menggunakan Strategi Pembelajaran Information Search Terhadap Kemampuan Menulis Teks Eksplanasi Kompleks. Hal ini akan mempengaruhi hasil belajar peserta didik, terutama pada ranah kognitif dan efektif karena sedikitnya informasi yang diterima peserta didik saat proses pembelajaran berlangsung.

Masalah

1. Strategi Pembelajaran Kurang Menarik

2. Siswa Pasif

3. Pemahaman Menulis Teks Ekspkanasi

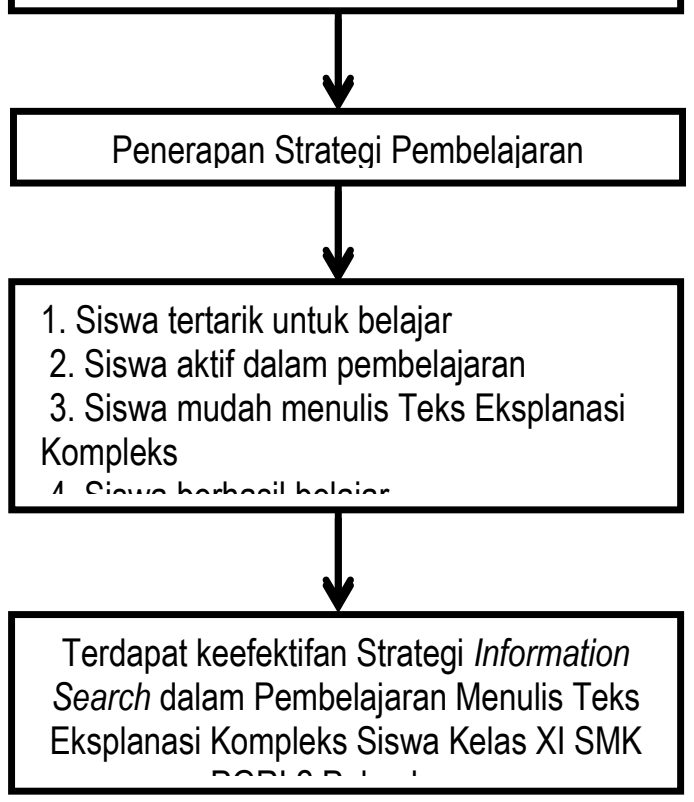

Strategi Pembelajaran merupakan meningkatkan hasil belajar siswa dan siswa dapat memiliki daya berinkuiri dan saling bekerjasama yang diperlukan suatu strategi yang disebut dengan Strategi Information Search yaitu strategi aktif yang memberikan kesempatan siswa untuk mencari informasi melalui media atau sarana apapun yang dapat memungkinkan dengan mendapatkan informasi tersebut.

Menurut Arikunto (2010), anggapan dasar adalah sebuah titik tolak pemikiran yang kebenarannya diterima oleh peneliti. Berdasarkan pengertian tersebut, maka penulis mengemukakan anggapan dasar sebagai berikut.

1) Pengajaran di SMK PGRI 2

Palembang memakai Kurikulum

Berbasis Kompetensi (KBK) dan Garis Besar Program Pengajaran 
Bahasa dan Sastra Indonesia Tahun 2018/2019.

2) Siswa kelas XI SMK PGRI 2 Palembang sudah mempelajari materi pembelajaran Information Search terhadap menulis teks ekplanasi kompleks.

Menurut Sugiyono, Hipotesis merupakan jawaban sementara terhadap rumusan masalah, di mana rumusan masalah penelitian telah dinyatakan dalam bentuk kalimat pertanyaan. Oleh karena itu, penulis mengajukan hipotesis sebagai berikut:

$\mathrm{H}_{1}$ : Ada pengaruh yang signifikan strategi pembelajaran Information Search terhadap kemampuan menulis teks eksplanasi kompleks.

Alasannya karena pengujian hipotesis dalam penelitian ini dilakukan untuk mengetahui signifikasi Pengaruh Strategi Information Search Terhadap Kemampuan Menulis Teks Eksplanasi Kompleks Siswa Kelas XI SMK PGRI 2 Palembang.

\section{METODOLOGI PENELITIAN}

Penelitian ini dilakukan dengan bereksperimen dimana satu kelas diberi perlakuan dengan menggunakan strategi Information Search sedangkan kontrol menggunakan kegiatan pembelajaran tentang menulis teks eksplanasi kompleks dan ceramah.

Populasi dalam penelitian ini adalah seluruh siswa kelas XI SMK PGRI 2 Palembang tahun pelajaran 2018/2019 yang berjumlah 62 siswa. Adapun populasi penelitian ini dapat dilihat pada tabel 1 , sebagai berikut.

\section{TABEL 1}

POPULASI PENELITIAN

\begin{tabular}{|c|c|c|c|c|}
\hline No & Kelas & $\begin{array}{c}\text { Laki- } \\
\text { laki }\end{array}$ & $\begin{array}{c}\text { Pere } \\
\text { mpua } \\
\mathbf{n}\end{array}$ & Jumlah \\
\hline 1 & $\begin{array}{c}\text { XI TSM } \\
\text { IND }\end{array}$ & 20 & 1 & 21 \\
\hline 2 & XI TSM 2 & 30 & - & 30 \\
\hline 3 & XI TKR & 31 & - & 31 \\
\hline
\end{tabular}

\begin{tabular}{|c|c|c|c|c|}
\hline & IND & & & \\
\hline Jumlah & 81 & 1 & 82 \\
\hline
\end{tabular}

Sumber: Tata Usaha SMK PGRI 2 Palembang

Berdasarkan Tabel 1 diketahui bahwa populasi penelitian ini untuk seluruh kelas XI berjumlah 82 siswa, terdiri dari 81 siswa laki-laki dan 1 siswa perempuan.

Dalam penelitian ini menggunakan metoderandom sampling atau sampel acak kelompok dalam pengambilan sampel. Selain itu Menurut Arikunto (2010) random sampling (secara acak) adalah pengambilan simpel yang dilakukan terhadap sampling unik (kelompok). Cara yang dilakukan adalah dengan mengundi. Adapun langkahlangkahnya, sebagai berikut:

1) Peneliti mendaftar semua kelompok populasi.

2) Setelah selesai didaftar, masingmasing kelas diberi nomor, masingmasing dalam satu kertas kecil-kecil.

3) Kertas-kertas kecil yang masingmasing telah diberi nomor kemudian digulung.

4) gulungan kertas yang telah berisi nomor-nomor tersebut, kemudian dimasukkan ke dalam kotak yang dapat digunakan untuk mengadukan tempatnya tersusun secara acak.

Setelah diambil acak, ternyata siswa kelas XI TSM IND sebagai kelas kontrol yang menjadi sampel penelitian ini untuk lebih jelasnya, sampel penelitian ini dapat dilihat pada tabel 2 , sebagai berikut.

TABEL 2

SAMPEL PENELITIAN

\begin{tabular}{|c|c|c|c|c|c|}
\hline $\begin{array}{c}\mathbf{N} \\
\mathbf{0}\end{array}$ & Kelas & $\begin{array}{c}\text { Lak } \\
\text { i- } \\
\text { Lak } \\
\mathbf{i}\end{array}$ & $\begin{array}{c}\text { Perem } \\
\text { puan }\end{array}$ & $\begin{array}{c}\text { Juml } \\
\text { ah }\end{array}$ & $\begin{array}{c}\text { Ketera } \\
\text { ngan }\end{array}$ \\
\hline 1 & $\begin{array}{c}\text { XI TSM } \\
\text { IND }\end{array}$ & 20 & 1 & 21 & $\begin{array}{c}\text { Eksperi } \\
\text { men }\end{array}$ \\
\hline 2 & $\begin{array}{c}\text { XI TSM } \\
2\end{array}$ & 30 & - & 30 & Kontrol \\
\hline & & 50 & 1 & 51 & \\
\hline
\end{tabular}


Berdasarkan Tabel 2 dapat diketahui bahwa sampel penelitian adalah siswa kelas XI TSM IND yang berjumlah 21 siswa sebagai kelas eksperimen atau kelas yang diajar menggunakan strategi Information Search, terdiri atas 1 perempuan dan 20 laki-laki. Sedangkan kelas XI TSM 2 yang berjumlah 30 siswa sebagai kelas kontrol atau kelas yang diajarkan tentang menulis teks eksplanasi kompleks dan ceramah, terdiri atas 30 laki-laki sedangkan siswa perempuan tidak ada/nihil.

Penelitian ini menggunakan tes dan wawancara sebagai teknik pengumpulan data. Tes adalah serangakaian pertanyaan atau latihan serta alat-alat lain yang digunakan untuk mengukur keterampilan, pengetahuan, intelegensi, kemapuan atau bakat yang dimiliki individu (Arikunto, 2010:150). Tes dilakukan sebanyak dua kali, yaitu pada setiap pertemuan baik pada kelas ekperimen maupun kelas kontrol. Materi tes mengacu aspek-aspek menulis teks eksplanasi kompleks. Tes digunakan untuk mengetahui pencapaian prestasi.

Tes yang digunakan adalah tes menulis teks eksplanasi setelah siswa mendapatkan pembelajaran menggunakan strategi pembelajaran Information Search.Untuk mengukur kemampuan siswa Kelas XII SMK PGRI 2 Palembang terhadap menulis teks eksplanasi kompleks yang menggunakan strategi Information Searchpeneliti menggunakan tes esai (menulis teks eksplanasi kompleks).

Wawancara adalah merupakan pertemuan dua orang atau lebih untuk bertukar informasi dan ide melalui tanya jawab, sehingga dapat dikonstruksikan makna dalam suatu topik tertentu (Sugiyono, 2010). Wawancara digunakan sebagai teknik pengumpulan data apabila seorang peneliti ingin melakukan studi pendahuluan untuk menemukan permasalahan yang harus diteliti tentang strategi Information Search (mencari informasi lengkap), dan apabila peneliti ingin mengetahui hal-hal responden yang lebih mendalam atau lengkap.

\section{Kisi-kisi Wawancara peneliti selama penelitian berlangsung, sebagai} berikut:

1) Mampukah siswa menulis teks eksplanasi?

2) Bagaimana lamanya guru mengajar di kelas?

3) Berapakah Jumlah siswa di kelas?

4) Apakah siswa mengalami kesulitan menulis teks eksplanasi selama pelajaran berlangsung?

5) Buku apa saja yang digunakan dalam materi tentang menulis teks ekspalanasi?

6) Apakah sebelumnya sudah menggunakan strategi pembelajaran Information Search terhadap kemampuan menulis teks eksplanasi kompleks siswa kelas XI SMK PGRI 2 Palembang?

7) Usaha apa yang dilakukan untuk mengembangkan pemahaman siswa tentang menulis teks eksplanasi kompleks?

Pengujian Reliabilitas Instrumen dapat dilakukan secara eksternal maupun internal. Secara eksternal pengujian dapat menggunakan Test-retest yang artinya instrumen penelitan yang reabilitasnya diuji dengan test-retest dilakukan dengan cara mencobakan instrumen beberapa kali kepada responded. Reabilitas diukur dari koefisien dari pencobaan pertama dengan yang berikutnya. Bila koefisien positif dan signifikan maka instrumen tersebut sudah dinyatakan reliabel dan menggunakan cara ini bisa disebut stabil, (Sugiyono, 2014). Rabilitas menunjukkan pada satu pengertian bahwa sesuatu instrumen cukup dapat dipercaya untuk digunakan sebagai alat pengumpulan data karena instrumen tersebut sudah cukup baik. Reabilitas instrumen merupakan pelengkap pengujian validitasi instrumen, oleh karena itu instrumen yang valid umumnya pasti reliabel terhadap 
pengujian instrumen yang dilakukan, (Arikunto, 2010:231).

Untuk teknik analisis data tes, dalam penelitian ini tes yang diberikan berupa tes menulis teks eksplanasi. Jumlah karangan adalah satu buah. Tes dikerjakan siswa secara berkelompok. Terlebih dahulu siswa diberi sejumlah pertanyaan atau informasi yang membahas topik tentang pendidikan. Siswa ditugaskan untuk mengumpulkan bahan tulisan yang dapat pula mengadakan observasi (pengamatan) terhadap sesuatu yang berkaiatan dengan topik yang dibicarakan.

\section{HASIL DAN PEMBAHASAN}

SMK $\begin{array}{r}\text { Penelitian ini dilaksanakan di } \\ \text { PGRI }\end{array}$ Penelitianiniberjudul"Pengaruh Strategi Pembelajaran Information Search Terhadap Kemampuan Menulis Teks Eksplanasi Kompleks Siswa Kelas XI SMK PGRI 2 Palembang.Tujuanpenelitianiniuntukmen getahuidanmendeskrisipsikanpengaruh strategi pembelajaran Information Search terhadap kemampuan menulis teks eksplanasi kompleks siswa kelas XI SMK PGRI 2 Palembang. Sebelum penelitian dilakukan peneliti terlebih dahulu mempersiapkan perangkat pembelajaran seperti silabus, rancangan pelaksanaan pembelajaran (RPP) dan instrumen soal tes berupa menulis teks eksplanasi kompleks. Tes diberikan kepada siswa baik yang menggunakan strategi pembelajaran Information Search maupun pembelajaran biasa. Setelah lengkap peneliti memberikan tes awal (pre-test) dan tes akhir (post-test).

Sampel yang digunakan dalam penelitian ini terdiri dari dua kelas yaitu: kelas XI TSM IND dengan jumlah siswa 25 siswa terdiri dari 1 siswa perempuan dan 24 siswa laki-laki sebagai kelas eksperimen. Untuk kelas kontrol terpilih kelas XI TSM 2 dengan jumlah siswa sebanyak 30 siswa laki-laki, jumlah keseluruhan sampel penelitian ini sebanyak 55 siswa terdiri dari 54 siswa laki-laki dan 1 siswa perempuan. Pokok bahasan penelitian ini adalah menulis teks eksplanasi kompleks. Penelitian dilaksanakan pada tanggal 5 Agustus s.d 19 agustus 2019. Penelitian ini dilakukan sebanyak 4 kali pertemuan, 1 x 60 menit ( $2 \mathrm{x}$ pertemuan) dengan 2 jam di kelas eksperimen dan 2 jam di kelas kontrol selama 4 kali pertemuan berturut-turut, dalam 1 minggu ada 4 jam pelajaran Bahasa Indonesia.

Penelitian ini memberikan perlakuan pembelajaran yang menggunakan pembelajaran tentang pengertian menulis teks eksplanasi kompleks kepada siswa kelas eksperimen dan kelas kontrol diberikan perlakuan yang menggunakan strategi Information Search. Untuk melengkapi data tes, peneliti juga menggunakan tes wawancara kepada guru mata pelajaran Bahasa Indonesia yang mengajar di kelas XI TSM IND 1 tes wawancara dilakukan pada tanggal 16 Agustus 2019.

Minggu Pertama, dilaksanakan pada hari Senin tanggal 5 Agustus 2019 pada kelas XI TSM IND (eksperimen) yang berlangsung pada jam ke enam pada pukul 10:30 - 11:15 dan jam ke tujuh pada pukul 11:15 - 12:15 WIB, pembelajaran dilaksanakan selama 2 jam pelajaran (1 x 60 menit) dengan kegiatan pembelajaran strategi Information Search dan minggu kedua (terakhir) peneliti memberikan pembelajaran tentang teks eksplanasi kompleks diiringi dengan tes akhir (post-test). Pada pertemuan pertama (minggu pertama) peneliti mengenalkan diri terlebih dahulu dan menjelaskan tujuan untuk mengadakan penelitian untuk menyelesaikan skripsi setelah perkenalan peneliti langsung masuk pelajaran tentang bagaimana pembelajaran strategi Information Search membuat teks eksplanasi kompleks yang sederhana. Siswa kurang memahami pelajaran teks eksplanasi kompleks. 


\begin{abstract}
Peneliti membuka pelajaran dengan mengucapkan salam, doa bersama-sama yang dipimpin oleh ketua kelas dan melihat daftar hadir sekaligus isi absen. Semua siswa hadir dalam peretemuan pertama (minggu pertama). Peneliti kemudian memberikan motivasi dan masukan kepada siswa bahwa setiap masing-masing siswa bisa menulis teks eksplanasi kompleks yang baik dan sederhana. Selanjutnya peneliti menerangkan pengertian menulis dan teks eksplanasi kompleks. dengan siswa diminta memperhatikan materi mengenai teks eksplanasi kompleks, lalu tahap selanjutnya peneliti menerapkan strategi pembelajaran Information Search yaitu, dengan: (1) Peneliti menyediakan materi yang sesuai pelajaran tersebut, buku paket Bahasa Indonesia SMK/SMA/MAK kelas XI edisi revisi/terbaru. (2) guru menggunakan alat untuk menunjang pengetahuan dan proses belajar agar terlaksanakan dengan baik, dalam mengajar menulis teks eksplanasi dengan proses pengalaman yang nyata seperti: papan tulis, spidol, penghapus, buku catatan siswa yang setiap harinya siswa simpan cacatan penting selama pelajaran dimulai. Akhirnya, setelah mengakhiri kegiatan pelajaran dengan mengucapkan salam.
\end{abstract}

Minggu Kedua, dilaksanakan pada hari senin tanggal 12 Agustus 2019 yang berlangsung jam ke lima pada pukul 10:45 - 11:45 dan jam ke enam pada pukul 11:45 - 12:15 WIB, di kelas XI TSM IND (Eksperimen) 1 x 60 menit selama 2 jam berakhir. Peneliti melanjutkan pada pertemuan terakhir dan menjelaskan kembali tentang materi pengertian menulis, tujuan menulis dan pengertian menulis teks eksplanasi kompleks dengan menggunakan strategi pembelajaran Information Search yang sederhana agar siswa mengingat kembali pelajaran sebelumnya. Selanjutnya peneliti melakukan post-tes kepada siswa peneliti mengawasi siswa sampai akhir waktu habis. sesudah itu peneliti mengucapkan salam berakhirnya pertemuan.

Minggu Pertama, dilaksanakan pada hari Senin tanggal 5 Agustus 2019 pada kelas XI TSM IND (eksperimen) yang berlangsung pada jam ke enam pada pukul 10:30 - 11:15 dan jam ke tujuh pada pukul 11:15 - 12:15 WIB. Pada pertemuan minggu pertama peneliti mengenalkan diri terlebih dahulu dan menjelaskan tujuan untuk mengadakan penelitian untuk menyelesaikan skripsi setelah perkenalan peneliti langsung masuk ke materi tentang menulis teks eksplanasi kompleks. Peneliti membuka pelajaran dengan mengucapkan salam dan melihat daftar hadir siswa peneliti menjelaskan tentang pengertian menulis teks dan teks eksplanasi kompleks dan memberikan contoh teks yang tertulis. Diakhir jam pelajaran peneliti mengucapkan terima kasih dan salam.

Minggu Kedua, dilaksanakan pada hari senin tanggal 12 Agustus 2019 yang berlangsung jam ke lima pada pukul 10:45 - 11:45 dan jam ke enam pada pukul 11:45 - 12:15 WIB, di kelas XI TSM IND (Eksperimen) 1 x 60 menit selama 2 jam berakhir. Pemberian tes akhir bertujuan untuk mengetahui pemahaman dan kemampuan siswa setelah mengikuti pembelajaran pada materi teks eksplanasi kompleks setelah diterapkan pembelajaran konvensional dengan ceramah singkat. Selanjutnya peneliti melakukan post-test pada siswa, peneliti mengawasi aktivitas siswa dan memberikan bantuan seperlunya setelah jam pelajaran habis siswa mengumpulkan tes menulis teks eksplanasi kompleks yang telah dibuat. Berakhirnya jam pelajaran dan pertemuan teakhir di minggu terakhir peneliti mengucapkan salam.

Untuk mendapat data penunjang, penelitian juga mewawancarai guru di SMK PGRI 2 Palembang. Identitas guru 
bahasa Indonesia yang mengajar di kelas XI SMK PGRI Palembang memiliki respon yang baik dalam wawancara penelitian ini adalah sebagai berikut.

$\begin{array}{ll}\text { Nama Guru } & \text { : Drs. Joni } \\ \text { Jenis Kelamin } & \text { : Laki-laki } \\ \text { Tempat/ Tanggal Lahir } & \text { Palembang, 18 } \\ & \text { November } 1960 \\ \text { Pendidikan Terakhir } & : \text { S2/Bahasa } \\ & \text { Indonesia }\end{array}$

1) Mampukah siswa menulis teks eksplanasi?

Jawaban: Menurut Bapak Joni pembelajaran menulis teks eksplanasi Kompleks di SMK PGRI 2 Palembang sudah dikatakan baik dan bisa.

2) Seberapa lama Bapak Joni mengajar di kelas?

Jawaban: 3 jam. Satu jam setengah sebelum istirahat dan satu jam setengah sesudah istirahat pelajaran.

3) Berapakah Jumlah siswa di kelas? Jawaban: 3 kelas.

4) Apakah siswa mengalami kesulitan menulis teks eksplanasi kompleks selama pelajaran berlangsung?

Jawaban: Tidak, siswa tidak mengalami kesulitan menulis teks eksplanasi kompleks setelah di berikan contoh sebelumnya.

5) Buku apa saja yang digunakan dalam materi tentang menulis teks ekspalanasi?

Jawaban: Bapak menggunakan buku cetak/ paket Bahasa Indonesia dan buku penunjang lainnya yang berhubungan dengan materi.

6) Apakah sebelumnya sudah menggunakan strategi pembelajaran Information Search terhadap kemampuan menulis teks eksplanasi kompleks siswa kelas XI SMK PGRI 2 Palembang?
Jawaban: Bapak belum pernah menggunakan Strategi Pembelajaran Information Search.

7) Usaha apa yang dilakukan untuk mengembangkan pemahaman siswa tentang menulis teks eksplanasi kompleks?

Jawaban: Usaha yang bapak lakukan yaitu menyuruh siswa lebih serius dalam menulis teks eksplanasi kompleks.

\section{Hasil Penelitian}

Dengan kegiatan observasi dilakukan secara samaan untuk mengamati kegiatan guru, serta hasil belajar siswa pada pembelajaran Bahasa Indonesia meggunakan pembelajaran Information Search terhadap kemampuan menulis teks eksplanasi kompleks.

Data hasil tes digunakan untuk hasil belajar yang dicapai siswa. Tes ditunjukkan kepada siswa yang menjadi sampel dalam penelitian ini dengan menggunakan perbandingan antara dua kelas, yaitu kelas eksperimen dan kelas kontrol. Peneliti memberikan tes kepada siswa setelah pokok materi selesai dibahas untuk mengumpulkan data tentang hasil belajar siswa, digunakan instrumen tes tertulis yaitu, membuat teks eksplanasi kompleks tentang fenomena alam. Berikut penulis paparkan hasil tes menulis teks eksplanasi tentang fenomena alam di kelas eksperimen dan kelas kontrol siswa kelas XI SMK PGRI 2 Palembang.

Untuk menguji data yang diperoleh dari penelitian digunakan analisis statistik. Teknik yang dipakai dalam penelitian ini dengan Uji $t$ yang digunakan untuk membandingkan hasil belajar rata-rata yang dicapai oleh siswa pada mata pelajaran Bahasa Indonesia yang merupakan media Strategi Pembelajaran Information Search maupun yang tidak menerapkan media Strategi Pembelaran tersebut. Untuk melakukan Uji t diperlukan uji normalitas 
dan uji homogenitas data dan untuk mengetahui merata atau tidaknya penyebaran data.

\section{Pembahasan}

Berdasarkan hasil tes menulis teks eksplanasi didapat sebelum pemberian perlakuan penerapan Strategi Information Search. Pada kelas eksperimen, diketahui nilai menulis teks eksplanasi kompleks dengan nilai terendah 75 dan tertinggi 92 nilai rata-rata 85,57 sedangkan hasil nilai menulis teks eksplanasi kompleks kelas kontrol terendah 75 dan tertinggi 98 nilai rata-rata 85,16 dari kedua kelas tersebut beberapa siswa mampu mencapai nilai yang baik.

Untuk mencapai pembelajaran yang lebih baik, tentunya dibutuhkan suatu strategi pembelajaran efektif untuk melengkapi proses pembelajaran. Dengan pembelajaran Information Search adalah strategi ini dapat memacu untuk berpikir dalam mencari jawaban. Strategi ini biasa disamakan dengan belajar buka buku (open book). Secara berkelompok siswa mencari informasi (biasanya tercakup dalam pembelajaran) yang menjawab tes soal yang diberikan kepada mereka. menurut Zaini, (2008: 48) "Strategi ini membantu menghidupkan materi pelajaran yang membosankan menjadi lebih menarik lagi." Dalam strategi ini peneliti memberikan pendekatan makna pada siswa kemudian tidak memberikan jawaban dan putusan terakhir dengan mereka.

Berdasarkan pada hasil penelitian yang diamati melalui lembar observasi ditemukan $100 \%$ siswa melakukan aktivitas yang positif baik dalam mencari informasi, menemukan bentuk kerjasama dan menentukan nilai yang dibalik materi. Hal ini memberikan gambaran adanya tingkat relevansi aktivitas yang positif dengan terjadinya peningkatan hasil belajar.

Hasil belajar menunjukkan bahwa adanya perbedaan kemampuan menulis teks eksplanasi antara siswa kelas eksperimen dam siswa kelas kontrol. Dengan adanya perbedaan tersebut, maka dapat dinyatakan bahwa strategi pembelajaran information search lebih efektif terhadap kemampuan menulis teks eksplanasi kompleks siswa kelas XI SMK PGRI 2 Palembang. Hal tersebut diketahui berdasarkan data yang diperoleh hasil dari menulis teks eksplanasi kompleks di kelas eksperimen dengan nilai terendah 75 dan tertinggi 92 . Sedangkan di kelas kontrol hasil dari menulis teks eksplanasi kompleks dengan nilai tertinggi 98 dan terendah 75 .

Berdasarkan data tes hasil belajar siswa dengan rata-rata nilai belajar siswa dikelas eksperimen 85,57 dan kelas kontrol dengan nilai 85,16. Setelah diperoleh data hasil tes siswa kelas eksperimen maupun kelas kontrol, maka peneliti melakukan analisis data tes tersebut. Analisis data dilakukan dengan menggunakan Uji t yang terdiri dari uji normalitas data uji homogenitas. Uji normalitas data dilakukan untuk mengetahui normal atau tidaknya suatu penyelesaian data, kemudian uji homogenitas diperlukan untuk membuktikan persamaan varians dari sampel.

Berdasarkan hasil perhitungan yang didapat untuk kelas eksperimen, uji normalitas data yang diperoleh $\mathrm{Km}=$ 0,98 sedangkan untuk kelas kontrol diperoleh $\mathrm{Km}=0,90$ dan nilai tersebut terletak anatara $(-1<\mathrm{K}<+1)$ sehingga dapat dikatakan data kelas eksperimen dan data kelas kontrol terdistribusi normal. Dengan hasil perhitungan dapat disimpulkan bahwa data penelitian yang diperoleh dari kelas eksperimen maupun kelas kontrol berarti homogen.

Setelah pengujian uji normalitas data dan uji homogenitas varians, data tersebut dinyatakan terdistribusi normal dan varians dalam penelitian ini bersifat homogen, maka tahap berikutnya adalah melakukan pengujian rumus Uji t dengan 
kriteria pengujian terima Ha jika $t_{\text {hitung }}>t$ tabel atau tolak Ho jika $t_{\text {hitung }}>t_{\text {tabel. }}$.

Dari hasil analisis data dengan menggunakan rumus uji $\mathrm{t}$ diperoleh $\mathrm{t}_{\text {hitung }}$ $=3,56$ dan $\mathrm{t}$ tabeldengan taraf signifikan $0,05 \%$ dengan diperoleh $\mathrm{t}$ tabel $=1,68$. Demikian, ternyata $t_{\text {hitung }}>t_{\text {tabel }(1-\alpha)}(3,56$ $>$ 1,68). Maka, hipotesis tentang ada pengaruh yang signifikan dengan menggunakan strategi pembelajaran Information Search terhadap kemampuan menulis teks eksplanasi kompleks siswa kelas XI SMK PGRI 2 Palembang" diterima.

\section{KESIMPULAN}

Dengan nilai data di kelas eksperimen dengan nilai menulis teks eksplanasi kompleks ditemukan hasil rata-rata secara keseluruhan 85,57 dan standar deviasi 5,33 dari 21 siswa. Hal ini menunjukkan nilai kelas eksperimen di atas termasuk normal dan merupakan hal yang wajar karena nilai siswa secara umumnya termasuk dalam kategori baik. Sementara, nilai rata-rata kelas kontrol sebagai kelas pembanding hasil nilai ratarata secara keseluruhan 85,16 dengan standar deviasi 5,31 dengan jumlah siswa berbeda yaitu 30 orang.

Berdasarkan hasil analisis data dalam penelitian ini dapat disimpulkan beberapa hal sebagai berikut:

1) Adanya data tes hasil belajar siswa, terdapat rata-rata nilai hasil belajar siswa dikelas eksperimen sebesar 85,57 dan kelas kontrol sebesar 85,16 . Hasil tes menulis teks eksplanasi kompleks menunjukkan bahwa hasil nilai siswa kelas eksperimen tidak jauh dibandingkan dengan hasil nilai siswa kelas kontrol.

2) Hasil analisis data dengan menggunakan rumus uji $t$ diperoleh $t$ hitung $=3,56$ dan $\mathrm{t}$ tabeldengan taraf signifikan $0,05 \%$ dengan diperoleh $\mathrm{t}$ ${ }_{\text {tabel }}=1,68$. Demikian, ternyata $t_{\text {hitung }}$ $>\mathrm{t}$ tabel (1- $\alpha)(3,56>1,68)$. Maka, hipotesis tentang ada pengaruh yang signifikan dengan menggunakan strategi pembelajaran Information Search terhadap kemampuan menulis teks eksplanasi kompleks siswa kelas XI SMK PGRI 2 Palembang" diterima.

\section{Saran}

Setelah melakukan penelitian tentang pengaruh strategi pembelajaran Information Search terhadap kemampuan menulis teks eksplanasi kompleks Siswa Kelas XI SMK PGRI 2 Palembang beberapa saran yang dapat peneliti berikan, yaitu sebagai berikut.

1) Bagi siswa, diharapkan dengan adanya penelitian ini dapat menambah pengetahuan dan meningkatkan kemampuan siswa dalam menulis teks eksplanasi kompleks dengan baik dan benar. Adanya keseriusan dalam mengikuti proses pembelajaran khususnya pada pelajaran Bahasa Indonesia menulis teks eksplkanasi kompleks dengan menggunakan strategi pembelajaran Information Search atau mencari informasi lengkap.

2) Bagi guru, diharapkan Strategi Pembelajaran Information Search dapatdijadikansalahsatu kegiatan menggunakan strategi pelajaran dalam kegiatan belajar maupun mengajar. Penggunaan media yang bervariasi akan lebih membantu guru dan siswa untuk mencapai tujuan pembelajaran. Dengan proses pelaksanaan pembelajaran menulis teks eksplanasi kompleks sebaiknya guru mempertimbangkan media yang akan digunakan.

3) Bagi peneliti, dengan hasil penelitian ini dapat digunakan sebagai informasi dan masukan untuk melaksanakan penelitian dengan menggunakan strategi pembelajaran Information Search terhadap 
kemampuan menulis teks eksplanasi kompleks sesuai dengan karakteristik siswa dan materi pelajaran.

4) Bagi sekolah, diharapkan penelitian ini digunakan untuk keinginan bermotivasi guru dengan upaya meningkatkan kualitas proses belajar maupun mengajar.

\section{DAFTAR PUSTAKA}

Aminudin, dkk, 2008. Pelajaran bahasa dan Sastra Indonesia. Jakarta. Pusat Perbukuan.

Arikunto, Suharsimi. (2006). Prosedur Penelitian Suatu Pendekatan Praktik.Jakarta: Rineka Cipta.

Arikunto, Suharsimi. 2017. Edisi 2.Dasar-Dasar Evaluasai Pendidikan.Jakarta: Bumi Aksara.

Arikunto, Suharsimi. 2013. ProsedurPenelitianSuatuPendeka tanPraktik. Jakarta: RinekaCipta.

Astuti, E Dwi. 2015. Bahasa Indonesia Untuk SMA/MA/SMK/MAK Kelas 10A. Solo: CV. HakaMj.

Burahman, Hendi. (2009). Model Pembelajaran(http://aloneducatio n..blogspot.com). Diakses tanggal 17 Desember 2014.

Dalman, H. 2012. Keterampilan Menulis. Jakara: PT Raja Grafindo Persada. Dalman.(2014). Keterampilan Menulis. Jakarta: Raja Grafindo Persada.

Hamruni 2011:161, Pengertian Information Search.

Hidayat, B. (2017). Peningkatan Kemampuan Menulis Teks Pidato dalam Pembelajaran Keterampilan Menulis Melalui Media Berbasis Audio. Jurnal Pembahsi (Pembelajaran Bahasa Dan Sastra Indonesia), 7(1), 28-41.
Kosasih, E. 2014. Strategi Belajar dan Pembelajaran. Bandung: Yrama Widya.

Kusumaningsih, Dewi. (2013).Terampil berbahasa Indonesia. Yogyakarta: Andi.

Marno dan Idris, (2008). Model dan Metode Pembelajaran. Jakarta: Sinar Baru

Algensindo.

Nurgiyantoro, 2009:152-153. Kriteria

Menulis Teks eksplanasi

Kompleks

Sudjana. 2002. Metode Statistika. Bandung: Penerbit Tarsito.

Sudjana. 2005. Metode Statistika. Bandung: Tarsito.

Sugiyono. 2009. Metode Penelitian Kuantitatif Kualitattif dan $R \& D$. Bandung: Penerbit Alfabeta.

Sugiyono. 2010. Metode Penelitian Kuantitatif Kualitattif dan $R \& D$. Bandung: Alfabeta.

Sugiyono. 2013. Statistik Untuk Penelitian. Bandung: Penerbit Alfabeta.

Suyati, S. (2019). Peningkatan keterampilan menulis teks prosedur menggunakan model pembelajaran resiprokal pada mata pelajaran b. Indonesia siswa kelas vii smp negeri 1 rambutan banyuasin. Jurnal pembahsi (pembelajaran bahasa dan sastra indonesia), 9(1), 66-74.

Tarigan, Henry Guntur. 2008. Menulis. Bandung: Angkasa.

Tarigan, Henry G. (2008). Menulis Sebagai Suatu Keterampilan Berbahasa. Bandung: Angkasa Bandung. 
PEMBAHSI JURNAL PEMBELAJARAN BAHASA INDONESIA Volume 11, No. 1 Tahun 2021

Wardarita, Ratu. (2010). Kemampuan

Menulis Karya Ilmiah.

Palembang:Pararaton. 